\title{
Detection of Parapoxvirus in goats during contagious ecthyma outbreak in Ceará State, Brazil by transmission electron microscopy techniques

\author{
Marcia Helena Braga Catroxo ${ }^{1 *}$, Martins A.M.C.R.P.F. ${ }^{2}$, Souza F. $^{3}$
}

\author{
Electron Microscopy Laboratory, Research and Development Center in Animal Health, Biological Institute, São Paulo, SP, \\ Brazil \\ *Corresponding Author: Marcia Helena Braga Catroxo \\ Biological Institute of São Paulo, SP, Brazil
}

\begin{abstract}
Contagious ecthyma or contagious pustular dermatitis, is a viral skin disease that occurs in sheep, goats and wild ruminants and is characterized by the formation of papules, nodules or vesicles that progress into thick crusts or heavy scabs on the lips, gingiva and tongue, caused by a member of the Parapoxvirus genus. Humans are occasionally affected constituting important zoonosis. The disease not only has an economic impact on farmers worldwide but also has a considerable negative effect on animal welfare. In this study, a contagious ecthyma outbreak which occurred in one flock with 90 goats located in the Ceará State, Brazil, was described. Twenty-two goats older than 6 months were affected. The animals presented crusted lesions on the buccal region, tongue, udder and teats, which began with swelling in the mouth area. Dried crusts and serum collected were processed for transmission electron microscopy utilizing, negative staining (rapid preparation), Immunocytochemistry (immunolabelling with colloidal gold particles) and resin embedding techniques. At the Philips EM 208 transmission electron microscopy all the samples were analyzed by negative staining technique and a great number of parapoxvirus particles ovoid or cylindrical, showing two morphological forms, a mulberry (M) form with a distinctive crisscross filament pattern derived from the superimposition of upper and lower virion surfaces and a capsular (C) form caused by stain penetration and distention of the virion core, measuring $300 \times 180 \mathrm{~nm}$ was observed. Antigen antibody reaction was increased by the colloidal gold particles. In the ultrathin sections of crusts, we verified the presence of three types of intracytoplasmic inclusion bodies, type A or Bollinger inclusion bodies, outlined by membrane, presented in it is interior, oval, mature or complete viral particles, measuring on the average, $225 \mathrm{~nm} x 130 \mathrm{~nm}$, showing an inner dumbellshaped core, two lateral bodies and an external envelope, or cigar shaped core. In the type B electron dense inclusions bodies, were visualized parapoxvirus particles budding of dense and amorphous material. Fibrillar intracytoplasmic inclusions were also found located between the virions, consisting of groups of fibrils, arranged in groups or concentrically in the middle of the granular material. Intracytoplasmic vesicles outlined by membranes, measuring $560 x 420 \mathrm{~nm}$, containing granular material in its interior were also observed. The nuclei showed an aspect deformed.
\end{abstract}

Keywords-Parapoxvirus, Goats, Transmission electron microscopy.

\section{INTRODUCTION}

Genus Parapoxvirus has four members, Orf virus (ORFV), Bovine papular stomatitis virus (BPSV), Pseudocowpoxvirus (PCPV) and Parapoxvirus of red deer in New Zealand (PVNZ). The ORFV is the prototype member.

Enveloped virions present with an ovoid shape and the spiral tubule surrounding the virion surface can be clearly distinguished by electron microscopy from orthopoxviruses (OPV) because of their regular surface structure. The particles of ORF virus are $260 \mathrm{~nm}$ length by $160 \mathrm{~nm}$ wide (Damon, 2007; Moss, 2007).

The virus genome includes linear double-stranded DNA about $138 \mathrm{~kb}$ length with $64 \% \mathrm{G}+\mathrm{C}$ content, which contains 132 putative genes that included 89 highly conserved genes and some variable genes. The envelope gene (P2L) of the virus encodes a highly immunogenic major envelope protein widely used for molecular characterization and phylogenetic analysis of strains of the virus (Inoshima et al., 2000; Delhon et al., 2004; Mercer et al., 2006; Zhang et al., 2010).

ORF virus is the etiological agent of the contagious ecthyma or contagious pustular dermatitis, a viral skin disease that occurs in sheep, goats and wild ruminants, characterized by the formation of papules, nodules or vesicles that progress into thick crusts or heavy scabs on the lips, gingiva, tongue, eyelids and feet and occasionally on the teats (Vikoren et al., 2008).

Susceptible animals usually develop the first signs of the disease 4 to 7 days after exposure that persists for 1 to 2 weeks or 
for large periods (Haig \& Mercer, 1998).

The mortality occurs, especially in young sucking lambs, due to an incidence of dehydration and starvation, as the pain and distortion of the lips and mouth preclude the lamb from sucking (Mombeni et al., 2012).

The mortality rate is usually low but it can reach $93 \%$ in lambs with secondary bacterial or fungal infections (Haig \& Mercer, 1998; Zhao et al., 2010).

The infection is spread by direct and indirect contact from infected animals or by contact with infected tissue or saliva containing the virus (Lojkic et al., 2007).

Outbreaks occur more frequently during periods of extreme temperatures such as late summer and winter (Robinson \& Balassu, 1981; Gokce et al., 2005).

Some infected animals become carriers and shed the virus for a long period (Mombeni et al., 2012).

Humans are occasionally affected constituting important zoonosis (Al Salam et al., 2008; Kitchen et al., 2013; Turan et al., 2013).

The disease not only has an economic impact on farmers worldwide but also has a considerable negative effect on animal welfare. Infected animals are sickly, fail to thrive, and are more susceptible to bacterial infections (Gallina et al., 2008).

Outbreaks of the disease have been reported in several countries, such as China (Zhang et al., 2010; Li et al., 2012), Croatia (Lojkic et al., 2010), Italy (Gallina et al., 2008), Japan (Inoshima et al, 2001), Taiwan (Chen et al., 2007) and Greece (Billinis et al., 2012).

In Brazil, a few reports were described in the states of Mato Grosso, MT (Abrahão et al., 2009); Pará, PA (Oliveira et al., 2012); Paraíba, PB (Nóbrega et al., 2008); Minas Gerais, MG, Rio Grande do Sul, RS e Pernambuco, PE (Mazur et al., 2000).

Considering the efficiency and speed of transmission electron microscopy techniques, this study aimed to detect the presence of parapoxvirus in skin lesions of goats during outbreak of contagious ecthyma first occurred in Ceará state, Brazil.

\section{MATERIAL AND METHOD}

\subsection{Description of the outbreak}

In this study, a contagious ecthyma outbreak occurred in the year 2011 in a flock with 90 goats located in the Ceará State, Brazil. Twenty-two goats older than 6 months were affected. The animals presented crusted lesions on the buccal region, tongue, udder and teats, which began with swelling in the mouth area that progressed to papules, vesicles, pustules and crusts. The mortality rate was $0 \%$ and the animals recovered 30 days after the onset of symptoms.

\subsection{Transmission Electron Microscopy}

Fragments of skin lesions and dry crusts and serum collected were processed for transmission electron microscopy utilizing negative staining (rapid preparation), immunocytochemistry (immunolabeling with colloidal gold particles) and resin embedding techniques.

\subsubsection{Negative staining technique (rapid preparation)}

In the negative staining process, the fragments of skin lesions and dry crusts were suspended in phosphate buffer $0.1 \mathrm{M}$ and pH 7.0 and placed in contact with metallic grids. Next, the grids were drained with filter paper and negatively stained at $2 \%$ ammonium molybdate pH 5.0 (Brenner \& Horne, 1959; Hayat \& Miller, 1990; Madeley, 1997).

\subsubsection{Immunocytochemistry technique.}

At the immunolabeling technique with colloidal gold particles for negative staining, the copper grids were placed in contact with viral suspension of the samples of skin lesions and dry crusts and, after removing the excess with filter paper, the same were put on specific primary antibody drops. After further washing in PBS drops, the grids were incubated in protein A drops, in association with $10 \mathrm{~nm}$ colloidal gold particles (secondary antibody). Grids were then contrasted with $2 \%$ ammonium molybdate at pH 5.0 (Knutton, 1995). 


\subsubsection{Resin embedding technique.}

Fragments of dry crusts were fixed in $2.5 \%$ glutaraldehyde in $0.1 \mathrm{M}, \mathrm{pH} 7.0$ phosphate buffer and post-fixed in $1 \%$ osmium tetroxide in the same buffer. After dehydration in cetonic series, the fragments were embedded in Spurr resin (GonzálezSantander 1969; Luft, 1961). Ultrathin sections were cut on the LKB ultratome and mounted on copper grids. The sections were contrasted with uranyl acetate-lead citrate (Watson, 1958; Reynolds, 1963).

All grids submitted to the above reactions were observed in a Philips EM 208 electron microscope, at $80 \mathrm{kV}$.

\section{RESULTS AND DISCUSSION}

\subsection{Transmission Electron Microscopy}

\subsubsection{Negative Staining Technique (Rapid Preparation)}

At the Philips EM 208 transmission electron microscope all the skin lesions and dry crusts samples examined by the negative staining technique showed a large number of parapoxvirus particles, ovoid or cylindrical, measuring $300 \mathrm{~nm}$ of length x $180 \mathrm{~nm}$ in diameter. Two morphological forms were visualized, a mulberry (M) form (fig. 1, big arrow) with a distinctive crisscross filament pattern derived from the superimposition of upper and lower virion surfaces and a capsular (C) form (fig. 2, minor arrow) caused by stain penetration and distention of the virion core.

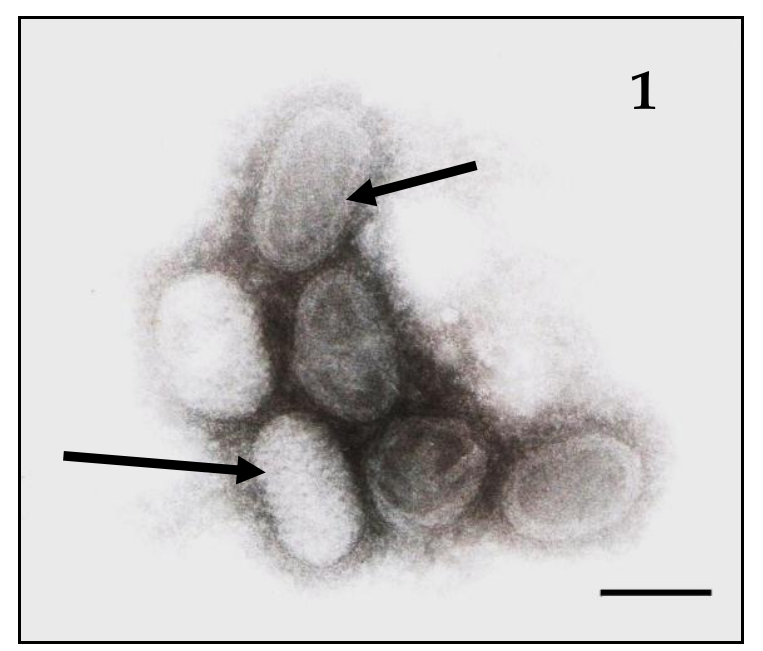

FIGURE 1: ELECTRON MICROGRAPH OF PARAPOXVIRUS IN CRUSTS SUSPENSION BY NEGATIVE STAINING, SHOWING A MULBERRY (M) FORM (BIG ARROW) WITH A DISTINCTIVE CRISSCROSS FILAMENT PATTERN DERIVED FROM THE SUPERIMPOSITION OF UPPER AND LOWER VIRION SURFACES AND A CAPSULAR (C) FORM (MINOR ARROW) CAUSED BY STAIN PENETRATION AND DISTENTION OF THE VIRION CORE. BAR: 180 nm.

\subsubsection{Immunocytochemistry Technique.}

In the immunocytochemistry technique, the antigen-antibody interaction was strongly enhanced by the dense colloidal gold particles over the parapoxvirus in all samples of skin lesions and dry crusts fragments (Figure 2, arrow), confirming the results of negative staining technique.

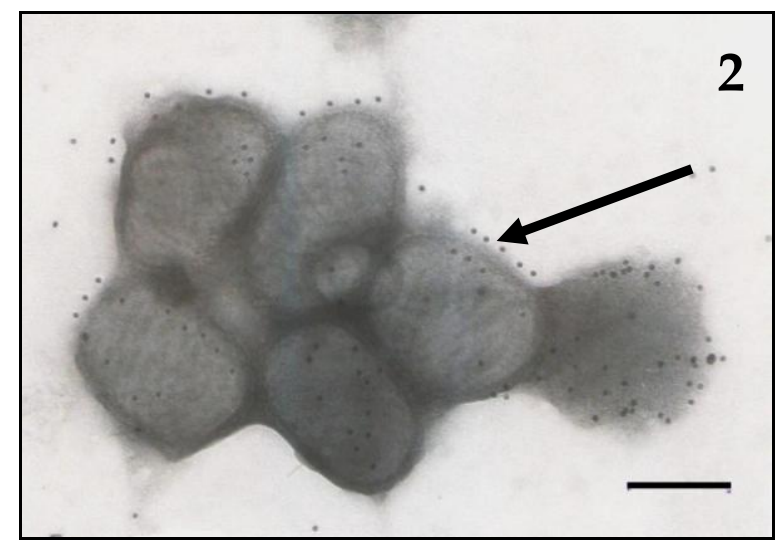

FIGURE 2: ELECTRON MICROGRAPH OF PARAPOXVIRUS GROUPING ENHANCED BY COLLOIDAL GOLD PARTICLES IN THE IMMUNOCYTOCHEMISTRY TECHNIQUE (ARROW). BAR: $140 \mathrm{~nm}$. 


\subsubsection{Resin Embedding Technique.}

In the ultrathin sections of crusts, we verified the presence of three types of intracytoplasmic inclusion bodies, type A or Bollinger inclusion bodies, type B or amorphous inclusion bodies and fibrillar inclusion bodies. Type A or Bollinger inclusion bodies (figs. 3,4), outlined by membrane, presented in it is interior, oval, mature or complete viral particles (figs. $\mathbf{3 , 4 , 5}$, arrow), measuring on the average, $225 \mathrm{~nm}$ of lenght $\mathrm{x} 130 \mathrm{~nm}$ of diameter, showing an inner dumbell-shaped core (fig.5, big arrow), two lateral bodies (fig. 5, minor arrow) and an external envelope (fig. 5, (arrowhead), or more often cigar shaped core (fig. 5, arrow blue). In the type B electron dense inclusions bodies, were visualized parapoxvirus particles budding of dense and amorphous material (figs. 6,7, arrow). Fibrillar intracytoplasmic inclusions were also found located between the virions, consisting of groups of fibrils, arranged in groups (fig. 8, big arrow) or concentrically in the middle of the granular material (fig. 6, blue arrow), with possible association with the initial stage of formation of the virion (fig. 8, minor arrow). These fibrils measured around 7-10 $\mathrm{nm}$ in diameter. Intracytoplasmic vesicles outlined by membranes, measuring $560 \times 420 \mathrm{~nm}$ of diameter, containing granular material in its interior were also observed (fig. 9, arrow). The nuclei showed a deformed aspect (fig. 10).

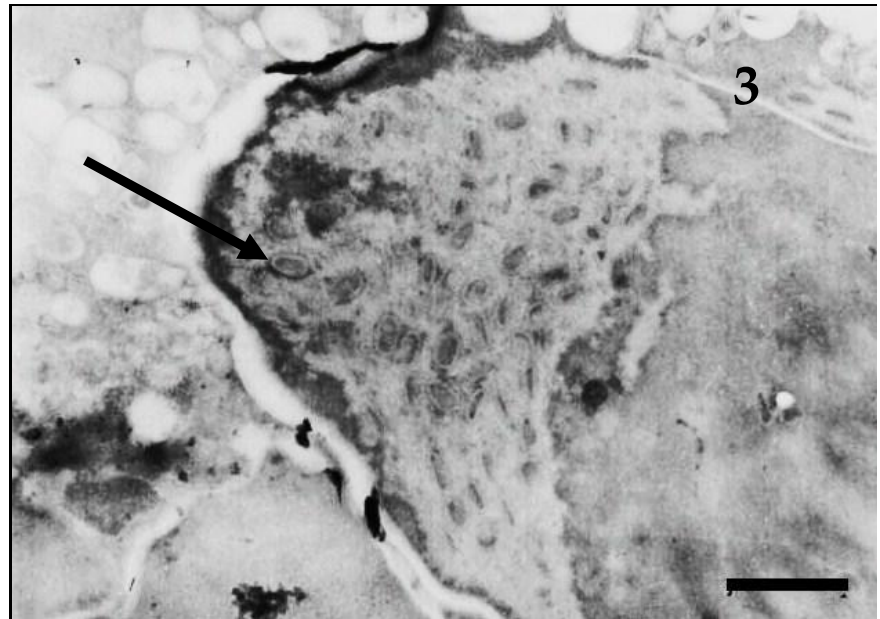

FIGURE 3: ULTRATHIN SECTION OF THE CRUSTS FRAGMENTS. OBSERVE TYPE A OR BOLLINGER INTRACYTOPLASMIC INCLUSION BODIES, PRESENTED IN ITS INTERIOR MATURE PARTICLES (ARROW). BAR: $640 \mathrm{~nm}$.

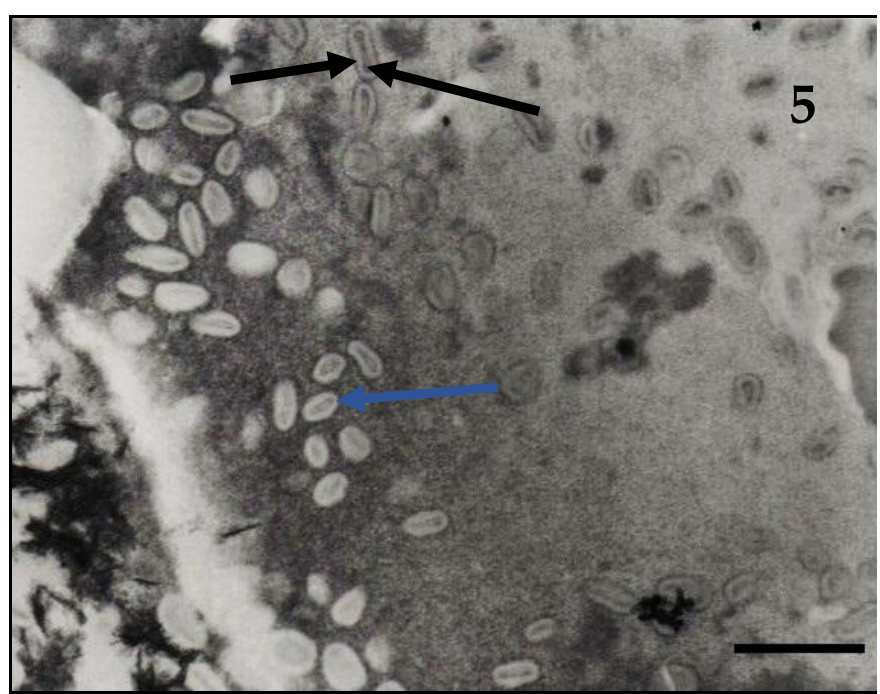

FIGURE 5: ULTRATHIN SECTION OF THE CRUSTS

FRAGMENTS. COMPLETE PARAPOXVIRUS PARTICLES SHOWING AN INNER DUMBELL-SHAPED CORE (BIG ARROW), TWO LATERAL BODIES (MINOR ARROW) AND AN EXTERNAL

ENVELOPE (ARROW HEAD), OR CIGAR SHAPED CORE (ARROW BLUE). BAR: $540 \mathrm{~nm}$.

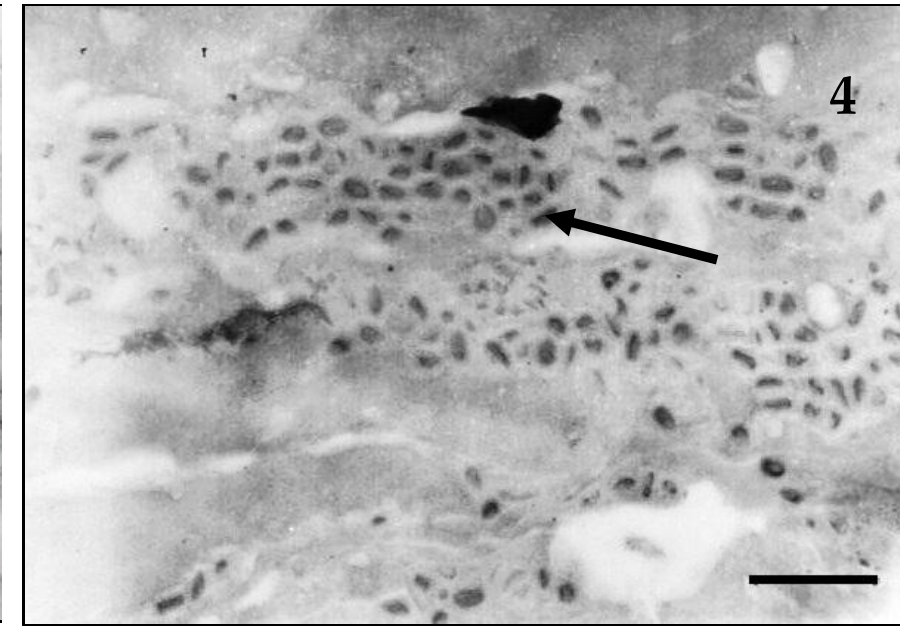

FIGURE 4: ULTRATHIN SECTION OF THE CRUSTS FRAGMENTS. TYPE A OR BOLLINGER INCLUSION BODIES CONTAINING GREAT NUMBER OF PARAPOXVIRUS PARTICLES (ARROW). BAR: $720 \mathrm{~nm}$.

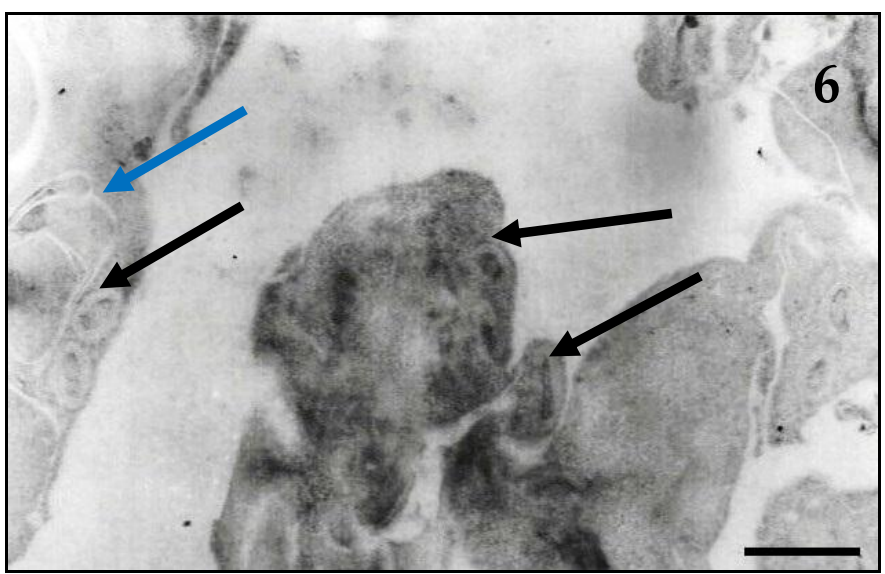

FIGURE 6: ULTRATHIN SECTION OF THE CRUSTS FRAGMENTS. TYPE B INCLUSION BODIES SHOWING PARAPOXVIRUS BUDDING OF DENSE AND AMORPHOUS MATERIAL (ARROW) AND FIBRILLAR INCLUSIONS (BLUE ARROW). BAR: $280 \mathrm{~nm}$. 


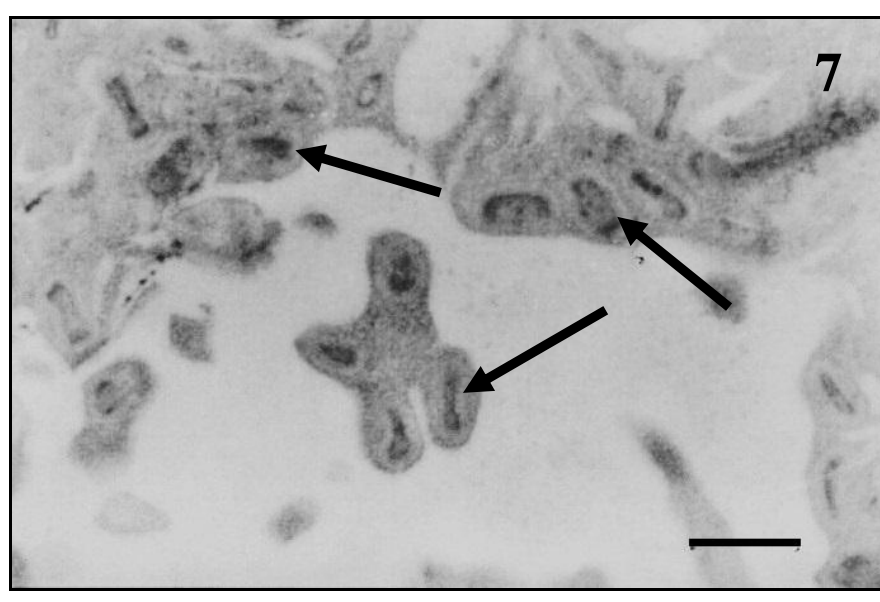

FIGURE 7: ULTRATHIN SECTION OF THE CRUSTS FRAGMENTS. TYPE B INCLUSION BODIES. OBSERVE GREAT NUMBER OF PARAPOXVIRUS PARTICLES BUDDING OF AMORPHOUS MATERIAL (ARROW). BAR: $260 \mathrm{~nm}$

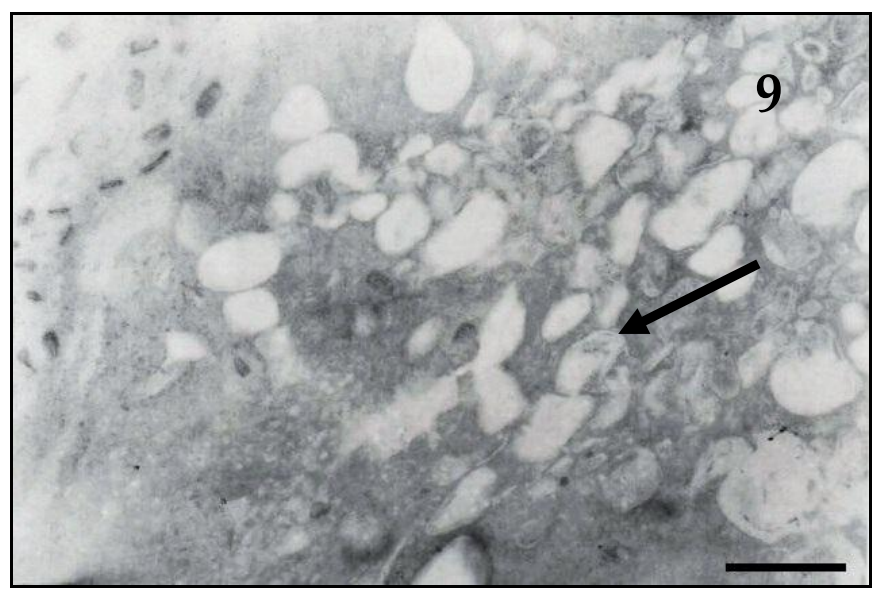

FIGURE 9: ULTRATHIN SECTION OF THE CRUSTS FRAGMENTS. VESICLES CONTAINING GRANULAR MATERIAL IN ITS INTERIOR (ARROW). BAR: $560 \mathrm{~nm}$.

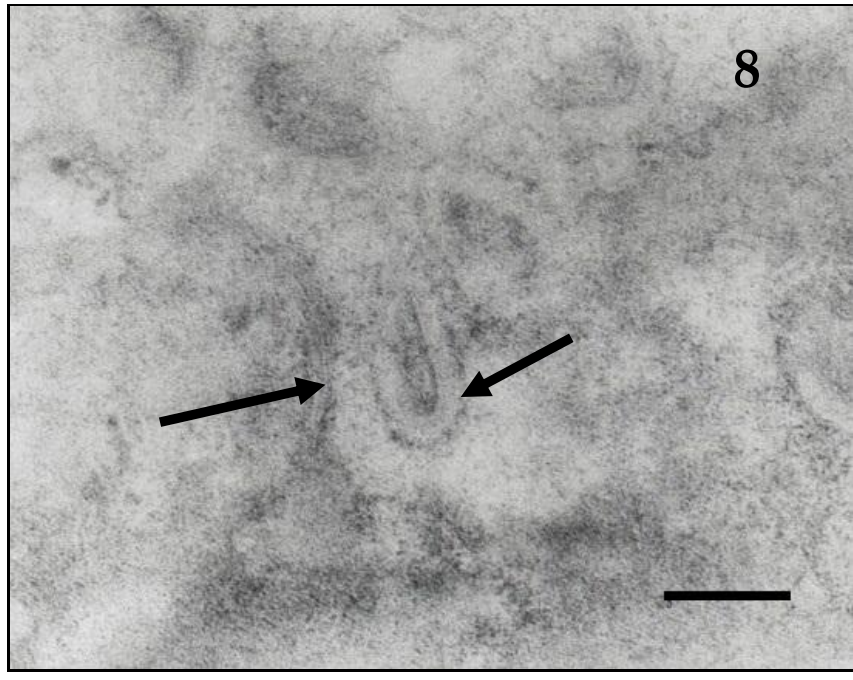

FIGURE 8: ULTRATHIN SECTION OF THE CRUSTS FRAGMENTS. FIBRILLAR INCLUSION CONSTITUTED BY

GROUPS OF FIBRILS (BIG ARROW), WITH POSSIBLE ASSOCIATION WITH THE INITIAL STAGE OF FORMATION OF THE VIRION (MINOR ARROW). BAR: $140 \mathrm{~nm}$

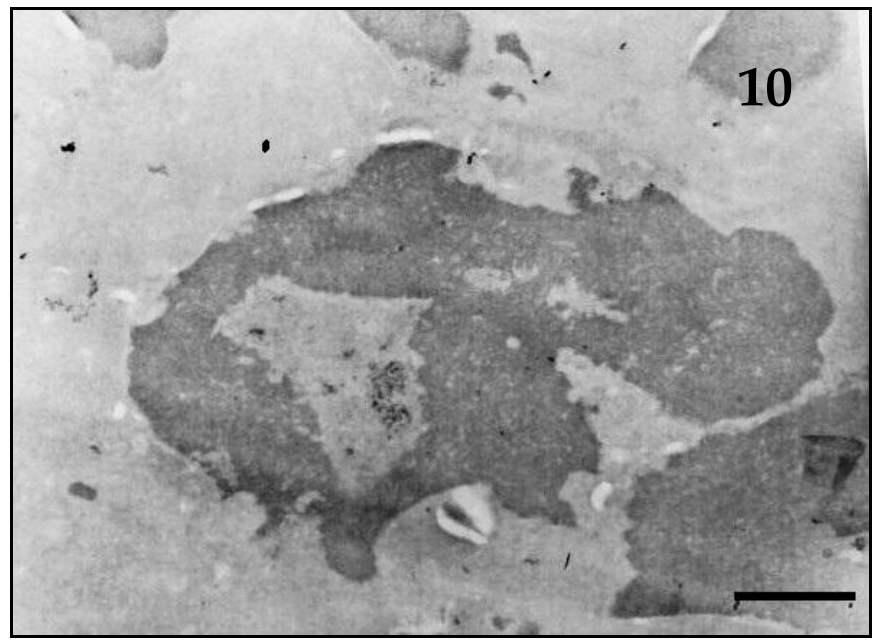

FIGURE 10: ULTRATHIN SECTION OF THE CRUSTS FRAGMENTS. OBSERVE NUCLEI WITH DEFORMED ASPECT. BAR: 720 nm.

In the study, a contagious ecthyma outbreak, which occurred in one flock with 90 goats located in the Ceará State, was described.

The clinical signs were characterized by lesions on the buccal region, tongue, udder and teats, with swelling in the mouth area that progressed to papules, vesicles, pustules and crusts.

Similar clinical signs were reported by other authors in research on contagious ecthyma in goats and sheeps (Inoshima et al., 2001; Nitsche et al., 2006; Chan et al., 2007; OIE, 2007; Abrahão et al., 2009; Oem et al., 2009; Lojkic et al., 2010; Zhang et al., 2010; Zhao et al.,2010; Shao-Peng et al., 2011; Billinis et al., 2012; Li et al., 2012; Mombeni et al., 2012; de Oliveira et al., 2012; Li et al., 2013).

Analogous lesions caused by parapoxvirus were also observed in camels (Gitao, 1994) and in a red deer (Scagliarini et al., 2011). Skin nodules located in head, neck and thorax, were reported in a sea lynx (Zalophus californianus) infected with parapoxvirus (Nollens et al., 2006).

The twenty-two affected goats of our study had 6 months of age, in agreement with other studies that showed that the disease affects animals from 3 to 6 months of age (Mombeni et al., 2012; Kinley et al; 2013). Younger animals with 2-3 weeks to 2 
months, however, can be seriously affected (Oem et al., 2009; Lojkic et al., 2010). Controversially, Abu \& Housawi (2009) and Gallina et al. (2008) stated that in adult goats the clinical signs might be more severe.

The mortality rate was $0 \%$ and the animals recovered 30 days after the onset of symptoms.

The low mortality rate is commonly reported, ranging from $0.8 \%$ to $24.7 \%$ (Chan et al.,2007; Abu \& Housawi, 2009; Zhao et al., 2010; Zhang et al., 2010; Shao-Peng et al., 2011; Li et al., 2012; Mombeni et al., 2012). Mortality due to starvation, however, was recorded in $80 \%$ of affected lambs owing to suckling difficulty was related (Lojkic et al., 2010). In young, stressed, or immunosuppressed sheep, formation of severe bloody lesions can be fatal (Nitsche et al., 2006).

Of the 90 flock, the disease affected 22 animals (24.4\%).

The morbidity rate was also variable among other studies, ranging from 6\% to 100\% (Chan et al.,2007; Abu \& Housawi, 2009; Oem et al., 2009; Lojkic et al., 2010; Zhao et al., 2010; Zhang et al., 2010; Shao-Peng et al., 2011; Li et al., 2012; Mombeni et al., 2012).

The diagnostic was realized by applying the techniques of transmission electron microscopy.

The negative staining technique detected typical parapoxvirus particles, ovoid or cylindrical, measuring $270 \mathrm{~nm}$ from length x $180 \mathrm{~nm}$ of diameter, morphological description also mentioned in other studies of contagious ecthyma (Gitao, 1994; Mazur et al. 2000; Torfason \& Gudnadottir, 2002; Mercer et al., 2006; Nollens et al., 2006; Chan et al., 2007; 2009; Mast \& Demestere, 2009; Oem et al., 2009; Cargnelutti et al., 2010; Zhao et al., 2010; Scagliarini et al., 2011; Shao-Peng et al., 2011; Kitchen et al., 2013). The two morphological forms, the mulberry (M) form, non-enveloped, with distinctive crisscross filament pattern and a capsular (C) form, enveloped, which we have visualized, were also described by Kitchen et al. (2013).

In ultrathin sections of crusts, we verified the presence of type A or Bollinger intracytoplasmic inclusion bodies, containing oval, mature or complete viral particles, measuring on the average, 225 x $130 \mathrm{~nm}$, showing an inner dumbell-shaped or cigar shaped core, ultrastructural aspects also reported by other authors (Muller et al., 2003; Nollens et al., 2006; Li et al., 2012).

We visualized inclusions of type B or amorphous inclusions, containing immature particles, budding from dense and amorphous material. These type of inclusion were observed in other poxvirus relates (Purcell et al., 1972; Thiele et al, 1979; Sadosiv et al., 1985; Bersano et al., 2003; Catroxo et al., 2009a,b).

In addition, we observed the fibrill intracytoplasmic inclusions previously described in studies on swinepox (Teppema \& Boer, 1975; Bersano et al., 2003), avianpox (Catroxo et al., 2009a) and myxomatosis (Catroxo et al., 2009b). These inclusions were located intranuclearly in the case of swinepox (Teppema \& Boer, 1975). According to Moss (1996), the initial stage of virion formation occurs in granular and electron-dense areas of the cytoplasm, separated from the cell membrane.

The presence of large numbers of intracytoplasmic vacuoles, surrounded by membranes, containing granular material, as well as deformed nuclei with dense chromatin is in accordance with other researches (Catroxo et al., 2009 a, b).

The immunocytochemistry technique we applied strongly marked the parapoxvirus particles with colloidal gold, allowing the visibility of the antigen-antibody interaction, also used by other researchers to confirm the poxvirus viral strain (Bersano et al., 2003; Catroxo et al., 2009 a,b) and to study the structure and morphogenesis of the ORF virus (Tan et al., 2009).

The diagnosis of contagious ecthyma was effectively concluded through the transmission electron microscopy techniques, being considered a classic tool and of the first line for diagnosis of poxvirus in swabs or crusts where the virus particles with their typical morphology are usually present in sufficient amount (Mercer et al., 2007).

Through this technique, parapoxvirus can easily be differentiated from orthopoxvirus by its different morphologies, with electron microscopy being one of the techniques chosen by the OIE to diagnose contagious ecthyma (Gitao, 1994; OIE, 2007).

In cases of lower viral loads, the problem can be contorned by the application of immuno-specific techniques, such as immunoelectron microscopy or immunolabeling with colloidal gold. Also in cases of not preserved material, the crusts can be processed by the resin embedding technique, followed by ultrathin sections, where in addition to the visualization of the viral particles, the cytopathic effects caused by the virus can be observed on the host cells (Catroxo et al., 2009 a,b). 
Considering that contagious ecthyma is a zoonosis, with public health implication, viral detection becomes important both in animals and in humans. Detection of parapoxviruses is fundamental for the exclusion of other rash-causing illnesses, in areas both veterinary and medical (Nitsche et al, 2006).

Contagious ecthyma may predispose animals to bacterial mastitis and it is therefore important to treat the lesions on the teats (OIE, 2008).

The introduction of new ORFV strains in Brazil seems to occur through the import of animals in order to improve herd genetics (Abrahão et al., 2009).

In order to avoid the risk of disease entry into herds and prevent economic losses resulting from it, important measures should be taken in livestock breeding. Proceed annual vaccination of young animals when the disease is endemic, always apply quarantine in the new animals before introducing them to the rest of the herd, surveillance on the introduction of diseased animals, and avoid stress factors and coarse grazing that cause abrasions on the skin and mucous membranes of the animals, facilitating the entry of the virus (OIE, 2007).

\section{CONCLUSION}

Considering that contagious ecthyma is a highly contagious, zoonotic, viral skin disease that affects sheep and goats, causing fail to thrive and decreases in production, the application of transmission electron microscopy techniques in routine or during outbreaks of the disease may help to develop measures for prevention and control of contagious ecthyma, collaborating with the National Goat and Sheep Health Program.

\section{REFERENCES}

[1] Abrahão J.S., Campos R.K., Trindade G.S., Guedes M.I., Lobato Z.I., Mazur C., Ferreira P.C., Bonjardim C.A. and Kroon E.G. 2009. Detection and phylogenetic analysis of Orf virus from sheep in Brazil: a case report. Virol. J. 6:47:1-4.

[2] Abu E.M. and Housawi F.M. 2009. Drastic cutaneous multi-focal orf infection in goats, causing severe dysfunctioning. Rev. Sci. Tech. 28:1025-1029.

[3] Al-Salam S., Nowotny N., Sohail M.R., Kolodziejek J., and Berger T.G. 2008. Ecthyma contagiosum (orf) - report of a human case from the United Arab Emirates and review of the literature. J. Cutan. Pathol. 35: 603-607.

[4] Bersano J. G., Catroxo M. H. B., Villalobos E. M. C., Leme M. C. M., Martins A. M. C. P. F., Peixoto Z. M. P.; Portugal M. A. S. C., Monteiro R. M., Ogata R. A. and Curi N. A. 2003. Varíola suína: estudo sobre a ocorrência de surtos nos estados de São Paulo e Tocantins, Brasil. Arq. Inst. Biol. 70:269-278.

[5] Billinis C., Mavrogianni V.S., Spyrou V. and Fthenakis G.C. 2012. Phylogenetic analysis of strains of Orf virus isolated from two outbreaks of the disease in sheep in Greece. Virol. J. 9:24:1-8.

[6] Brenner S. and Horne R. W. 1959. A negative staining method for high resolution electron microscopy of viruses. Biochem. Biophys. Acta. 34:103-110.

[7] Cargnelutti J.P., Schmidt C., Weiblen R. and Flores E.F. 2010. Ectima contagioso. Boletim Informativo do Deparatmento de Medicina Veterinária do Centro de Ciências Rurais da Universidade Federal de Santa Maria (UFSM), RS, 4:1-4.

[8] Catroxo M.H.B., Pongiluppi T., Melo N. A., Milanelo L., Petrella S., Martins A.M.C.P.F. and Rebouças M.M. 2009a. Identification of poxvirus under transmission electron microscopy during outbreak period in wild birds, in São Paulo, Brazil. Int. J. Morphol. 27:577-585.

[9] Catroxo M.H.B., Bersano J. G., Martins A. M. C. P. F., Petrella S., Portugal M. A. S. C. and Souza O. S. 2009b. Ultrastructural study of poxvirus causing myxomatosis in rabbits, in São Paulo and Santa Catarina, Brazil. Int. J. Morphol. 27:543552.

[10] Chan, K.-W., Lin J.-W., Lee S.-H., Liao C.-J.,Tsai M.-C., Li Hsu W.-L.,Wong M.-L. and Shih H.-C. 2007. Identification and phylogenetic analysis of orf virus from goats in Taiwan. Virus Genes 35:705-712.

[11] Damon I. Poxviridae and their replication. In: Fields Virology, New York, Raven Press Ltd., 2007, pp. 2079-2081.

[12] Delhon G., Tulman, E.R., Afonso C.L., Lu Z., Concha-Bermejillo A., Lehmkuhl H.D., Piccone M.E., Kutish G.F., and Rock D.L. 2004. Genomes of the parapoxviruses Orf virus and bovine papular stomatitis virus. J. Virol. 78:168-177.

[13] Gallina L., Scagliarini L., C. J. McInnes C.J., Guercio A., Purpari G., Prosperi S. and Scagliarini A. 2008. Parapoxvirus in goats: experimental infection and genomic analysis. Vet. Res. Commun. 32: S203-S205.

[14] Gitao C.G. 1994. Outbreaks of contagious ecthyma in camels (Camelus dromedarius) in the Turkana district of Kenya. Rev.sci.tech.Off.int.Epiz.13:939-945.

[15] Gokce H.I., Genc O. \& Gokce G. 2005. Sero-prevalence of contagious ecthyma in lambs and humans in Kars, Turkey. Turk. J. Vet. Anim. Sci. 29:95-101.

[16] Gonzalez-Santander R. Técnicas de microscopia electrónica en biología. Madrid, Ed. Aguilar, 1969, p.666.

[17] Haig D.M. and Mercer A.A. 1998. Ovine diseases. Orf. Vet. Res. 29:311-326.

[18] Hayat M.A. and Miller S.E. Negative Staining. New York: Mc Graw Hill Publ. Company, 1990, p.235. 
[19] Inoshima Y., Morooka A. and Sentsui H. 2000. Detection and diagnosis of parapoxvirus by the polymerase chain reaction. J. Virol. Methods. 84:201-208.

[20] Inoshima Y., Murakami K.,Yokoyama T. and Sentsui H. 2001. Genetic heterogeneity among parapoxviruses isolated from sheep, cattle and Japanese serows (Capricornis crispus). J. Gen. Virol. 82:1215-1220.

[21] Kinley G.E., Schmitt C.W. and Stephens-Devall J. 2013. A case of contagious ecthyma (Orf Virus) in a nonmanipulated laboratory dorset sheep (Ovis aries). Case Rep. Vet. Med. 1-5.

[22] Kitchen M., Müller H., Zobl A., Windisch A., Romani N., and Huemer H. 2013. Orf virus infection in a hunter in Western Austria, presumably transmitted by game. Acta. Derm. Venereol. 94:212-214.

[23] Knutton S.1995. Electron microscopical methods in adhesion. Methods. Enzymol. 253:145-158.

[24] Li H., Zhu X., Zheng Y., Wang S., Liu Z., Dou Y., Li H., Cai X., and Luo X. 2013. Phylogenetic analysis of two Chinese orf virus isolates based on sequences of B2L and VIR genes. Arch. Virol.158:1477-1485.

[25] Li W., Ning Z., Hao W., Song D., Gao F., Zhao K., Liao X., Li M., Rock D.L. and Luo S. 2012. Isolation and phylogenetic analysis of orf virus from the sheep herd outbreak in northeast China. BMC Vet. Res. 8:229:1-13.

[26] Lojkic I., Zeljko Cac Z., Beck A., Bedekovic T., Cvetnic Z. and Sostari B. 2010. Phylogenetic analysis of Croatian orf viruses isolated from sheep and goats. Virol. J. 7:314, 2-7.

[27] Luft J.H. 1961. Improvements in an epoxy resin embedding methods. J. Biophys. Biochem. Cytol. 9:409-414.

[28] Madeley C.R. 1997. Origins of electron microscopy and virus diagnosis. J. Clin. Pathol. 50:454-456.

[29] Mast J. and Demeestere L. 2009. Electron tomography of negatively stained complex viruses: application in their diagnosis. Diag. Pathol. 4:5-7.

[30] Mazur C., Ferreira I.I., Rangel Filho F.B. and Galle R. 2000. Molecular characterization of Brazilian isolates of orf virus. Vet. Microbiol. 73:253-259.

[31] Mercer A.A., Schmidt A. and Weber O. Poxviruses. In: Birkhauser Advances in Infectious Diseases, Birkhauser Verlag, Basel, 2007, pp. 1-45, pp. 113-166, pp. 355-373.

[32] Mercer A.A., Ueda N., Friederichs S., Hofmann K., Fraser K.M., Bateman T. and Fleming S.B. 2006. Comparative analysis of genome sequences of three isolates of Orf virus reveals unexpected sequence variation. Virus Res.116:146-158.

[33] Mombeni E.G., Mousavi M.B., Ranjbaran I., Chanani Z., Hoseini M., Davoudi A., Rahnama A., Sedeh N.S. and Mombeini M.G. 2012. Prevention and treatment of contagious ecthyma in sheep and goat by goat-pox vaccine in Khuzestan Province, Iran. Bull. Env. Pharmacol. Life Sci. 1:69- 72.

[34] Moss B. Poxviridade: the viruses and their replication, in: Fields Virology, v.2, Fields B.N, Knipe D.M., Howley P.M. Eds. Philadelphia: Lippincott-Raven, 1996, pp.2637-2671.

[35] Muller G., Groters S., Siebert U., Rosenberger T., Driver J., Konig M., Becher P., Hetzel U. and Baumgartner W. 2003. Parapoxvirus infection in harbor seals (Phoca vitulina) from the German North Sea. Vet. Pathol.40:445-454.

[36] Nitsche, A., Buttner M., Wilhelm S., Pauli G. and Meyer H. 2006. Real-Time PCR detection of parapoxvirus DNA. Clin. Chem. 52:316-319.

[37] Nóbrega Jr J.E., Macedo J.T.S.A., Araújo J.A.S., Dantas A.F.M., Soares M.P. and Riet-Correa F. 2008. Ectima contagioso em ovinos e caprinos no semi-árido da Paraíba. Pesq. Vet. Bras. 28:135-139.

[38] Nollens H.H., Jacobson E.R., Gulland F.M.D., Beusse D.O., Bossart G.D., Hernandez J.A., Klein P.A. and Condit R.C. 2006. Pathology and preliminary characterization of a parapoxvirus isolated from a California sea lion (Zalophus californianus). J. Wildl. Dis. 42:23-32.

[39] Oem J.-K., Roh I.-S, Lee K.-H., Lee K.-K., Kim H.-R., Jean Y.-H., and Lee O.-S. 2009. Phylogenetic analysis and characterization of Korean orf virus from dairy goats: case report. Virol. J. 6:167:1-5.

[40] OIE Contagious Ecthyma. Manual of diagnostic for terrestrial animals. The Center for Food Security \& Public Health. OIE, Paris, France, 2007. P.1-4.

[41] Oliveira C.H.S., Assis F.L., Neto J.D.B., Oliveira C.M.C., Lopes C.T.A., Bomjardim H.A., Vinhote W.M.S., Silva A.G.M., Abrahão J.A. and Kroon E.G. 2012. Multifocal cutaneous orf virus infection in goats in the Amazon region, Brazil. Vector Borne Zoonotic Dis. 12:336-340.

[42] Purcell D.A., Clarke J.K. McFerran B.J. and Hughes D.A. 1972. The morphogenesis of pigeonpox virus. J. Gen. Virol.15:79-83.

[43] Reynolds E.S. 1963.The use of lead citrate at high pH as an electron-opaque stain in electron microscopy. J. Cell. Biol. 17:208-212.

[44] Robinson A.J. and Balassu T.C.1981. Contagious pustular dermatitis (ORF). Vet. Bull. 52:771-782.

[45] Sadosiv E.C. Chang P. W. and Gulka G. 1985. Morphogenesis of canary poxvirus and its entrance into inclusion bodies. Am.J.Vet.Res. 46:529-535.

[46] Scagliarini A., Vaccari F., Turrini F., Bianchi A., Cordioli P. and Lavazza A. 2011. Parapoxvirus infections of red deer, Italy. Emerg. Inf. Dis. 17:684-687.

[47] Shao-peng G.U., Xin-tao S., Zhong-yong S., Zhong-bing W. and Ming-xue Z. 2011. Identification and phylogenetic analysis of an orf virus isolated from an outbreak in boer goat in Shanxi Province. Agr.Sci. China. 10:946-953.

[48] Tan J.L., Ueda N., Mercer A.A. and Fleming S.B. 2009. Investigation of ORF virus structure and morphogenesis using recombinants expressing FLAG-tagged envelope structural proteins: evidence for wrapped virus particles and egress from infected cells. J.Gen.Virol. 90:614-625.

[49] Teppema J.S. and de Boer G.F. 1975. Ultrastructural aspects of experimental swinepox with special reference to inclusion bodies. Arch. Virol. 49:151-163. 
[50] Thiele J. Kiel H. and Adolphs H.D. 1979. Avian pox virus. An ultrastructural study on a cherrug falcon. Brief report. Arch. Virol. 62:77-82.

[51] Torfason E.G. and Gudnadottir S. 2002. Polymerase chain reaction for laboratory diagnosis of Orf virus infections. J. Clin. Virol. 24:79-84.

[52] Turan E., Yesilova Y. and Ucmak D. 2013. A case of orf (ecthyma contagiosum) with multiple lesions. J. Pak. Med. Assoc. 63:786787.

[53] Vikoren T., Lillehaug A., Akerstedt J., Bretten T., Haugum M. and Tryland M. 2008. A severe outbreak of contagious ecthyma (orf) in a free-ranging musk ox (Ovibos moschatus) population in Norway. Vet. Microbiol.127:10-20.

[54] Watson M.L. 1958. Staining of tissue sections for electron microscopy with heavy metals. J. Biophyis. Biochem. Cytol. 4:475-478.

[55] Zhang K., Shang Y., Jin Y., Wang G., Zheng H., He J., Lu Z. and Liu X. 2010. Diagnosis and phylogenetic analysis of Orf virus from goats in China: a case report. Virol. J. 7:121.

[56] Zhao K., Song D., He W., Lu H., Zhang B., Li C., Chen K. and Gao F. 2010. Identification and phylogenetic analysis of an Orf virus isolated from an outbreak in sheep in the Jilin province of China. Vet. Microbiol. 142:408-415. 